\title{
Determination of suitable areas for organic production in Kelkit basin and mapping by geographical information systems ${ }^{\dagger}$
}

\author{
Hakan Karadağ (DD ${ }^{1 *}$, Kenan Yıldız (iD) ${ }^{1}$ Hakan Mete Doğan (D)2 \\ ${ }^{1}$ Tokat Gaziosmanpaşa University, Faculty of Agriculture, Department of Horticulture, Tokat-Turkey \\ ${ }^{2}$ Tokat Gaziosmanpaşa University, Faculty of Arts and Sciences, Departmentof Geography, Tokat-Turkey \\ This study is derived from Hakan KARADAĞ's doctoral thesis.
}

\section{ABSTRACT}

Kelkit Basin contains 17 districts within the boundaries of Tokat, Amasya, Gümüşhane, Giresun, and Sivas provinces. The Basin is located in the Middle Black Sea Region of Anatolia, at 40.9968 North, 30.8491 East, 36.0482 South, and 36.6943 West coordinates. The total area of the basin is $16.244,45$ hectares. The altitude of the basin surrounded by high mountains ranged from $200 \mathrm{~m}$ (base of the valley) to $1200 \mathrm{~m}$ (high plain). The height of the mountains gradually increased from west to east until $2400 \mathrm{~m}$. There is not any major industry establishment limiting the level of organic agriculture in the basin. The main livelihood of the people in the region is agriculture. Our study aimed to determine and mapping the suitable areas for organic agriculture in the basin. For this purpose, land surveys were conducted, point data were collected with GPS and the 1230-point value are calculated. On the calculation of point value, Land Use Capability, land pollution situation, erosion risk groups, and soil groups are used as criteria. In line with the regulation of organic farming practices, in the calculation the amount of pollution; intense agricultural activity, the impact of roads, settlement influence, water resources, the effects of soil pollution, and industrial-mining areas were taken into account. By using these calculated values, maps were created in the program ArcGIS (9.3) by analysis of IDW (Inverse Distance Weighted). According to the generated maps, the organic agricultural potential of the region was put forward.
\end{abstract}

\section{ARTICLE HISTORY}

Received: 25 March 2021

Accepted: 10 June 2021

\section{KEYWORDS}

Global Positioning System Organic Agriculture

Kelkit Basin

IDW

\section{* CORRESPONDING}

hakan.karadag@gop.edu.tr

\section{Introduction}

The rapid growth of the world population brought together many needs. The most important of these is the need for nourishment. Satisfy the nourishment needs of the world's population has become one of the most important problems of the last century. According to the UN "global replacement fertility" will be reached equalize around 2045. In 2025, 8.5 billion people will live in the world, perhaps 9.4 billion (Kennedy, 2000). All countries make scientific and technological investments to meet people's the nutritional needs. As a result of these investment, rapidly increasing intensive farming has also led to some problems. Agriculture has had a significant effect on global warming (Korkmaz, 2007). Measuring the years 2014-2015 and 2016 as the hottest times of the last 130 years and rising ocean temperatures have caused global warming to become one of the busiest topics on the world's agenda in recent years. Alternative solutions have begun to be produced due to the agricultural wastes, which are considered as one of the sources of global warming, and organic agriculture has become the forefront.
According to WHO data, it has experienced an increase in nourishment-related cancer events in the world. In the direction of this increase, it is emphasized that in 2020, 50\% of cancer event will be caused by wrong nourishment and obesity (Dönmez, 2008). According to FAO data (2018a), 4 million tons of pesticides, and 120 million tons of chemical fertilizers were used worldwide. In Turkey, as of 2017, the chemical fertilizer using for agricultural production has reached a size of 2.6 million tons (FAO, 2018b). Organic farming; provides a great added value to the business economy because it is a planned production type that provides the maximum benefit by reducing the use of external inputs (Dolun, 2003).

Organic agriculture is a rapidly developing industry all over the world. The organic farming area, which was 11 million hectares in 1999, has reached an area of about 50 million hectares today. In Turkey, it has managed to keep pace with this rapid increase, and the amount of organic agriculture land has a rate of $2.16 \%$ in total agricultural land (Fao, 2016). The first organic farming activities in Turkey started in 1984-1985 intending to export, in line with the wishes of European companies which are importers. For the 
first time, it was made in Turkey in the Aegean Region with dried figs and raisins (Rehber and Turan, 2002; Demiryürek, 2004; Deniz, 2009). According to the Ministry of Agriculture and Forestry, the amount of "Organic Products" are around 250 (2015) and increasing day by day (Anonymous, 2015a,b). Initially, the trade of Organic Products with the European Union has developed rapidly and has reached many big markets like the USA, Japan.

The lack of serious industrial development to pollute the ecology presents great opportunities for new development approaches for the region. The region's Organic Farming is located in the well-known area Niksar and "Niksar Organic Fruit Producer Association" was established in 2009 by a group of producers. Within the Kelkit basin, there is a professional enterprise with a capacity of 1000 cows producing organic milk and other small-scale family businesses in the basin.

Kelkit basin is an important region because of its agriculture potential and biodiversity. Updated thematic maps that contain detailed geographic information are extremely important for the area to establish a good basis for a healthy economic development (Doğan, 2009). This study will reveal the organic agriculture potential of the Kelkit Basin and will be a resource for producers, investors and politicians. The maps produced have the potential to assist decision makers.

\section{Materials and methods}

\subsection{Working area}

The area called Kelkit Basin is located between the borders of Amasya, Tokat, Sivas, Giresun, Gümüşhane, and Erzincan. The basin covers 15 districts and a total of $16.244,45 \mathrm{~km}^{2}$ area. The location of the basin is 40.9968 North, 30.8491 East, 36.0482 West, and 39.6943 South coordinates (Figure 1).

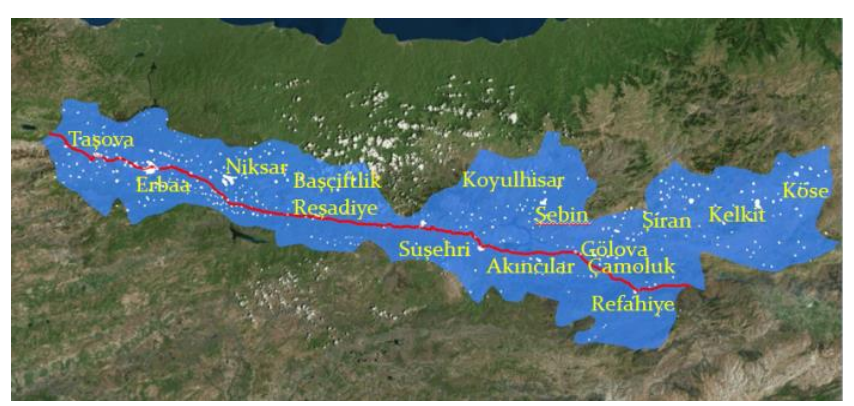

Figure 1. Kelkit basin satellite image.

The Kelkit valley is one of the rare regions of Turkey that have not suffered serious destruction and pollution. The basin is located between the Black Sea region and Central Anatolia. Since it is located in the geographical transition zone, the region has abundant natural resources and biological diversity. The altitudes of the region vary between 200 and 1200 meters as it goes west to east. Having a climatic zone between the Black Sea and Central Anatolia, The Kelkit valley offers climatic advantages. In the study conducted by Doğan and Kılıç (2013a) using LOCCLIM (Local Climate Estimator) software developed by FAO, the spatial distribution of some climate values as an annual average of the basin was investigated. The average temperature in the basin ranges from $6.87{ }^{\circ} \mathrm{C}$ to $12.2{ }^{\circ} \mathrm{C}$. The maximum temperature values range from $13.45{ }^{\circ} \mathrm{C}$ to 17.91 ${ }^{\circ} \mathrm{C}$ and are low in the southern and eastern parts of the basin and higher in the western and northern parts of the basin. The lowest temperatures range from $0.59{ }^{\circ} \mathrm{C}$ to $7.47{ }^{\circ} \mathrm{C}$. The average annual precipitation of the basin varies between $30.58 \mathrm{~mm}$ and $69.36 \mathrm{~mm}$. Potential evapotranspiration values range from $66.56 \mathrm{~mm}$ to $81.89 \mathrm{~mm}$. The basin with abundant rainfall exhibits the features of the Black Sea vegetation cover. According to the Davis grid system (Davis, 1971; Davis, 1988), the Kelkit basin is located within grid squares A6 and A7. Some species in the region are indicative of the Mediterranean climate (Karaer, 1994). There is a maximum of brown forest soils in the region and these lands compose about half of the basin.

In the scope of the study, ArcGIS 9.3 software was used for the creation of the Kelkit basin (land use capability, pollution, topography, soil structure) database and the generation of maps (ESRI, 1997). In the study, maps of suitable areas for organic agriculture were established within the basin areas. 1230 random points that can represent the basin were identified. Places known to have characteristics in land surveys were also added to the evaluation points. Thus, a comparison of the actual use cases of the evaluation points has also been made. In the Kelkit basin there are 15 districts and approximately 1200 villages connected to the districts. Within the scope of the study, approximately 600 villages that reflect the characteristics of the region were visited and field surveys were carried out in two years. Certified organic production area information was obtained from the Provincial Directorate of Agriculture, checked and evaluated on site. During the field studies, interviews were made with the producers, the product pattern and land information of the region were obtained. The remaining samples were made on the map by selecting them according to their similar characteristics to the visited areas.

\subsection{Determination of organic agriculture ineligible areas}

In the study, 17 district centers, 510 village centers, 20 industrial - mining areas, and an E80 highway were identified on the basin map. The identified areas were marked as polygons on the basin map and they were calculated. To minimize the effect of the settlement on the organic farming activities, a distance of $500 \mathrm{~m}$ buffer was set around the determined polygons to give the effect distance. For these areas, the organic farming score was applied as "0" (Anonymous, 2011; Anonymous, 2015c).

\subsection{Parameters used and scoring parameters}

The following formula has been used for the calculation of identified point's organic farming score (Table 1). In the formula, pollution is the biggest effect on the organic farming score. The impact rate of pollution was determined as $70 \%$ (Anonymous, 2011).

Informing the formula, not only pollution also other factors effecting agricultural activities are added to the evaluation criteria. According to the Land Use Capability (LUC) classes, the most suitable areas for agricultural activities I to $\mathrm{V}$ classes were used. The erosion risk areas map has been used as a source and the areas have designated as point data that have been overlapped with the erosion risk map (Kılıç, 2015). The identified points were overlapped on Large Land Soil Group maps and evaluated for soil groups. 
Soil groups were graded I to V (Doğan et al., 2013b; Kılıç, 2015).

Table 1. Parameters used for calculating organic agriculture value of sampling points

\begin{tabular}{|l|ll|}
\hline \multirow{3}{*}{$\begin{array}{l}\text { Organic } \\
\text { Agriculture }\end{array}$ Score $=$} & Land Use Capability Score & $\times 0.1$ \\
\cline { 2 - 3 } & Erosion risk areas & $\times 0.1$ \\
\cline { 2 - 3 } & Large Soil Groups & $\times 0.1$ \\
\cline { 2 - 3 } & Pollution Score & $\times 0.7$ \\
\hline
\end{tabular}

\subsection{Pollution}

Sub-parameters of pollution were calculated as follows, pollution of identified points data were found (Anonymous, 2011).

The parameters were established by evaluating the land pollution and pollution sources in line with the organic agriculture regulation (Table 2). Areas with intensive farming were determined by taking into consideration the land surveys, the LUC class, and the agricultural activities applied. According to the intensive agriculture activity of the sampling points have scored between 0 and 5 (Anonymous, 2011). The lack of water pollution caused by agricultural activities and industrial wastes in the basin gives advantages for organic agriculture. All sampling points in terms of water pollution got 5 points.

Table 2. Parameters used for calculating pollution value of sampling points

\begin{tabular}{|l|ll|}
\hline \multirow{4}{*}{$\begin{array}{l}\text { Pollution } \\
\text { Coefficient }\end{array}$} & Road Impact & $\times 0.05$ \\
\cline { 2 - 3 } & Settlement Impact & $\times 0.05$ \\
\cline { 2 - 3 } & Intense Farming Activity & $\times 0.2$ \\
\cline { 2 - 3 } & Soil Pollution & $\times 0.2$ \\
\cline { 2 - 3 } & Water Pollution & $\times 0.1$ \\
\cline { 2 - 3 } & Industry and Mining Areas & $\times 0.1$ \\
\hline
\end{tabular}

According to the analyses results of the year 2014-2015 made by Ministry of Agriculture and Forestry, pesticide residue was found at 1 point in Erbaa province. No heavy metal remains were found at any sampling point in the Kelkit basin according to the results of the survey and analyses conducted at 250 points (Kılıç, 2015).

\subsection{Calculation of point values}

The method used to calculate the scores for the sampling points and the section of the generated excel page of the method is given in Table 3 and 4 (Etko, 2015).

\subsection{Mapping operations}

The ArcGIS 9.3 program was used to process and evaluate maps. Mapping operations were performed using the Inverse Distance Weighted Interpolation Technique (IDW) which is one of the most common techniques. IDW is an analytical method that forms a surface from data by creating a line with predominant combinations of point data (Childs, 2004; Arslanoğlu and Özçelik, 2005). Based on the method, there is a decrease in cellular value as move away from the point where it is valued (Figure 2) (ESRI 2016). Using the mathematical calculation formula formed by Shepard (1968) as the basis of the IDW method (Lillesand, 2000; Arslanoglu and Özçelik, 2005; Üstantaş,
2006; Demircan et al., 2011; Doğan et al., 2013b; Demircan et al., 2014).

$F(x, y)=\sum_{i=1}^{n}$ wifi

$\mathrm{wi}=\frac{h i^{-p}}{\sum_{i=1}^{n} h i^{-p}}$

The function is expressed in terms of any base distance, inversely proportional to the weight used in the estimation (2). Here, the "p" value indicates the exponential. The sum of the "wi" values representing the weights must be 1 . The function finds the value of the unknown point giving more weight to nearby ones while giving less weight to distant ones (Doğan et al., 2013a).

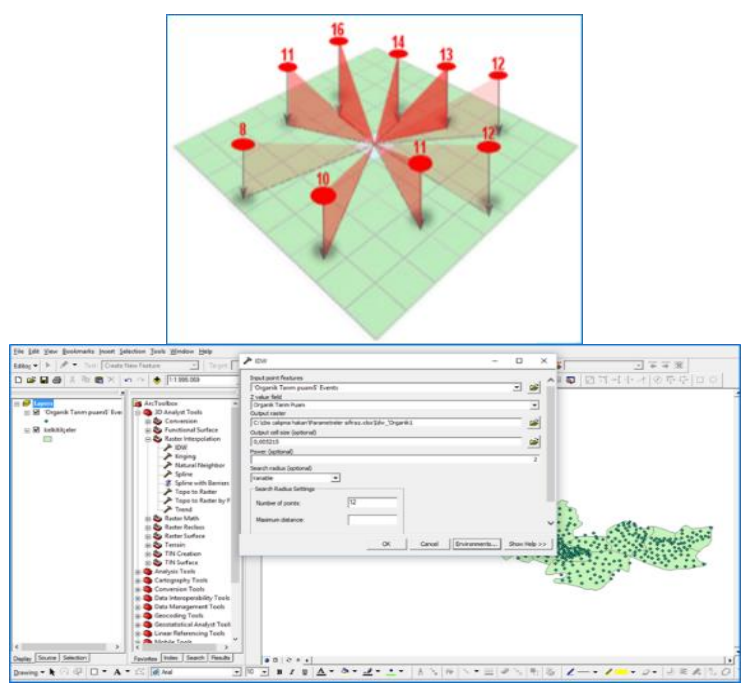

Figure 2. IDW method and application on the ArcGIS

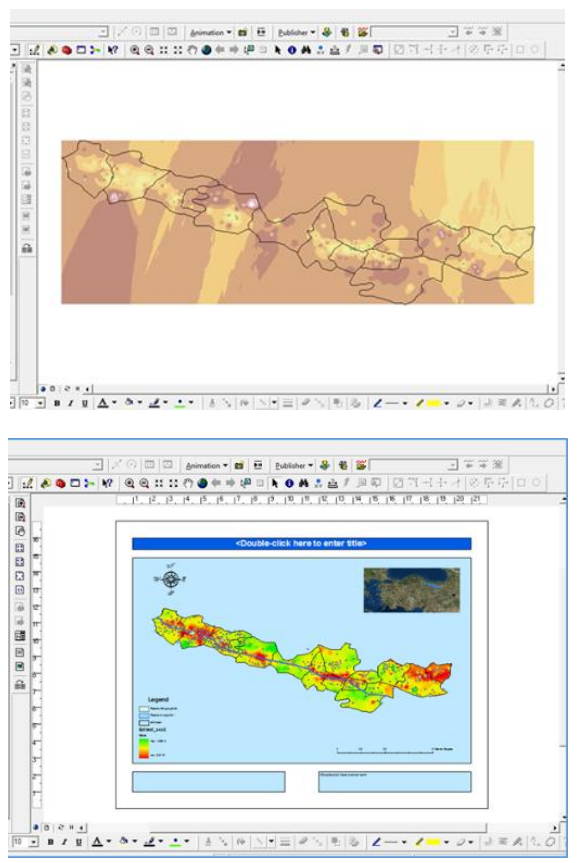

Figure 2 (Continue). IDW method and application on the ArcGIS 
Table 3. Excel table section for calculation of the organic farming score

\begin{tabular}{|c|c|c|c|c|c|c|c|c|c|c|c|c|c|c|c|}
\hline \multirow{2}{*}{$\begin{array}{l}\text { Sample } \\
\text { Point }\end{array}$} & \multirow{2}{*}{$\begin{array}{c}\text { Altitude } \\
(\mathrm{m})\end{array}$} & \multirow[t]{2}{*}{ Altitude } & \multirow[t]{2}{*}{ Longtitude } & \multirow{2}{*}{$\begin{array}{l}\text { Organic Agriculture Score } \\
\text { of Points }\end{array}$} & \multicolumn{4}{|c|}{ Land Use Capability (LUC) } & \multirow{2}{*}{$\begin{array}{c}\text { Pollution } \\
\text { Impact } \\
\text { Score }\end{array}$} & \multicolumn{3}{|c|}{ Road Impact } & \multicolumn{3}{|c|}{ Settlement Impact } \\
\hline & & & & & LUC Rate & $\begin{array}{l}\text { Land } \\
\text { class }\end{array}$ & $\begin{array}{l}\text { Impact } \\
\text { score }\end{array}$ & Coefficient & & $\begin{array}{c}\text { Impact } \\
\text { rate }\end{array}$ & $\begin{array}{c}\text { Impact } \\
\text { score }\end{array}$ & Coefficient & $\begin{array}{c}\text { Impact } \\
\text { rate }\end{array}$ & $\begin{array}{c}\text { Impact } \\
\text { score }\end{array}$ & Coefficient \\
\hline Eg. 1 & 567 & 36.1117374 & 40.69536717 & 4.3 & 0.2 & 4 & 2 & 0.1 & 3.5 & 0.25 & 5 & 0.05 & 0.25 & 5 & 0.05 \\
\hline Eg. 2 & 535 & 36.13161832 & 40.69900957 & 4.4 & 0.3 & 3 & 3 & 0.1 & 3.5 & 0.25 & 5 & 0.05 & 0.25 & 5 & 0.05 \\
\hline Eg. 3 & 1180 & 36.14459069 & 40.80027226 & 4.4 & 0.1 & 5 & 1 & 0.1 & 3.5 & 0.25 & 5 & 0.05 & 0.25 & 5 & 0.05 \\
\hline \multicolumn{16}{|l|}{ “ } \\
\hline Eg. 719 & 1830 & 39.5697841 & 40.22216849 & 4.2 & 0.1 & 6 & 1 & 0.1 & 3.5 & 0.25 & 5 & 0.05 & 0.25 & 5 & 0.05 \\
\hline
\end{tabular}

Table 3. (Continued) Excel table section for calculation of the organic farming score

\begin{tabular}{|c|c|c|c|c|c|c|c|c|c|c|c|c|c|c|c|c|c|c|c|}
\hline \multicolumn{3}{|c|}{ Intense Farming Activity } & \multicolumn{3}{|c|}{ Soil Pollution } & \multicolumn{3}{|c|}{ Water Pollution } & \multicolumn{3}{|c|}{ Industry-Mining Area Impact } & \multicolumn{4}{|c|}{ Erosion Risk Areas } & \multicolumn{4}{|c|}{ Large Soil Groups } \\
\hline $\begin{array}{c}\text { Impact } \\
\text { rate }\end{array}$ & $\begin{array}{c}\text { Impact } \\
\text { score }\end{array}$ & Coefficient & $\begin{array}{c}\text { Impact } \\
\text { rate }\end{array}$ & $\begin{array}{c}\text { Impact } \\
\text { score }\end{array}$ & Coefficient & $\begin{array}{c}\text { Impact } \\
\text { rate }\end{array}$ & $\begin{array}{c}\text { Impact } \\
\text { score }\end{array}$ & Coefficient & $\begin{array}{c}\text { Impact } \\
\text { rate }\end{array}$ & $\begin{array}{c}\text { Impact } \\
\text { score }\end{array}$ & Coefficient & $\begin{array}{c}\text { Impact } \\
\text { rate }\end{array}$ & $\begin{array}{l}\text { Impact } \\
\text { score }\end{array}$ & $\begin{array}{l}\text { Land } \\
\text { class }\end{array}$ & Coefficient & $\begin{array}{c}\text { Impact } \\
\text { rate }\end{array}$ & $\begin{array}{c}\text { Impact } \\
\text { score }\end{array}$ & $\begin{array}{l}\text { Land } \\
\text { class }\end{array}$ & Coefficient \\
\hline 1 & 5 & 0.2 & 1 & 5 & 0.2 & 0.5 & 5 & 0.1 & 0.5 & 5 & 0.1 & 0.3 & 3 & 2 & 0.1 & 0.3 & 3 & 3 & 0.1 \\
\hline 1 & 5 & 0.2 & 1 & 5 & 0.2 & 0.5 & 5 & 0.1 & 0.5 & 5 & 0.1 & 0.3 & 3 & 2 & 0.1 & 0.3 & 3 & 3 & 0.1 \\
\hline 1 & 5 & 0.2 & 1 & 5 & 0.2 & 0.5 & 5 & 0.1 & 0.5 & 5 & 0.1 & 0.3 & 3 & 2 & 0.1 & 0.5 & 5 & 7 & 0.1 \\
\hline 1 & 5 & 0.2 & 1 & 5 & 0.2 & 0.5 & 5 & 0.1 & 0.5 & 5 & 0.1 & 0.1 & 1 & 4 & 0.1 & 0.5 & 5 & 7 & 0.1 \\
\hline
\end{tabular}

Table 4. Sub-criteria and sub-criterion scores of land criteria

\begin{tabular}{|c|c|c|c|c|c|c|c|c|c|c|c|c|c|c|c|c|c|}
\hline \multicolumn{2}{|c|}{$\begin{array}{l}\text { Land Use Capability } \\
\text { (LUC) }\end{array}$} & \multicolumn{2}{|c|}{ Road Impact } & \multicolumn{2}{|c|}{ Settlement Impact } & \multicolumn{2}{|c|}{$\begin{array}{l}\text { Industry-Mining Area } \\
\text { Impact }\end{array}$} & \multicolumn{2}{|c|}{ Intense Farming Activity } & \multicolumn{2}{|c|}{ Soil Pollution } & \multicolumn{2}{|c|}{ Water Pollution } & \multicolumn{2}{|c|}{ Erosion Risk Areas } & \multicolumn{2}{|c|}{ Large Soil Groups } \\
\hline Land class & Score & $\begin{array}{c}\text { Closeness } \\
\text { to main } \\
\text { road }\end{array}$ & Score & $\begin{array}{c}\text { Closeness to } \\
\text { settlement }\end{array}$ & Score & $\begin{array}{l}\text { Closeness } \\
(3 \mathrm{~km} \\
\text { buffer })\end{array}$ & Score & $\begin{array}{l}\text { Around the } \\
\text { sample point }\end{array}$ & Score & Pollution+ & 0 & Pollution+ & 0 & Rik group & $\begin{array}{c}\text { Scor } \\
\mathrm{e}\end{array}$ & Soil Group & Score \\
\hline I. class land & 5 & Close & 0 & Close & 0 & 0 & 5 & $>10 \%$ & 5 & Pollution- & 5 & Pollution- & 5 & Lowest risk & 5 & $\begin{array}{c}\text { Brown forest } \\
\text { soil }\end{array}$ & 5 \\
\hline $\begin{array}{c}\text { II. class } \\
\text { land }\end{array}$ & 4 & $\begin{array}{c}\text { Far }(>500 \\
\mathrm{m})\end{array}$ & 5 & $\operatorname{Far}(>3 \mathrm{~km})$ & 5 & $\operatorname{Far}(>3 \mathrm{~km})$ & 5 & $11-30 \%$ & 4 & & & & & Low risk & 4 & Brown soil & 4 \\
\hline $\begin{array}{l}\text { III. class } \\
\text { land }\end{array}$ & 3 & & & & & & & $31-50 \%$ & 3 & & & & & Middle & 3 & $\begin{array}{c}\text { Grey-brown } \\
\text { podzolic soil }\end{array}$ & 3 \\
\hline $\begin{array}{l}\text { IV. class } \\
\text { land }\end{array}$ & 2 & & & & & & & $51-70 \%$ & 2 & & & & & High risk & 2 & Koluvial soil & 2 \\
\hline $\begin{array}{l}\text { VI. class } \\
\text { land }\end{array}$ & 1 & & & & & & & $71-90 \%$ & 1 & & & & & $\begin{array}{l}\text { Highest } \\
\text { risk }\end{array}$ & 1 & $\begin{array}{l}\text { Hidroformic } \\
\text { soil }\end{array}$ & 1 \\
\hline & & & & & & & & $91-100 \%$ & 0 & & & & & & & $\begin{array}{c}\text { Brown forest } \\
\text { soil }\end{array}$ & 5 \\
\hline
\end{tabular}




\section{Results}

\subsection{Map of organic agriculture}

The suitable areas and classifications for organic farming in the Kelkit basin are shown on the map (Figure 3). According to legend, the white color means, not suitable areas for organic farming that are the settlement, industrial and mining areas. It is stated in the organic agriculture regulation that these areas are not suitable for organic agriculture and its application is left to the Control and Certification firms.

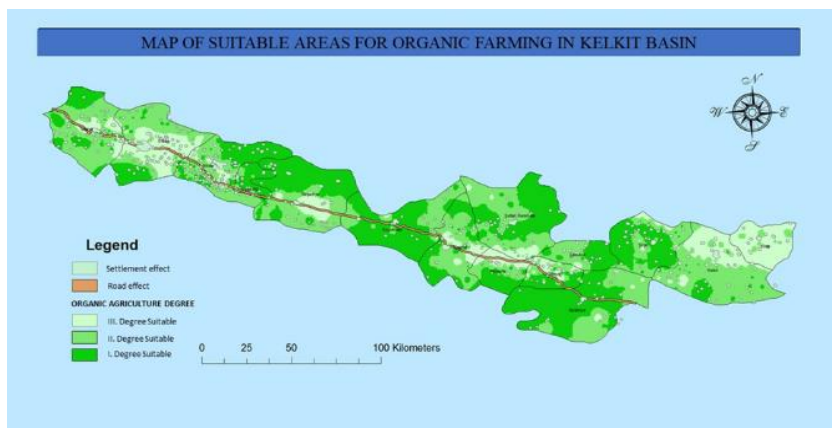

Figure 3. Map of suitable areas for organic farming in Kelkit basin

The red line area symbolizes the E80 highway passing, through the basin from top to bottom a total of 250 kilometers. A buffer of 1 kilometer has been applied to determine the road effect. Suitable areas for organic farming are classified as grade 1 , grade 2 , grade 3 . The class which emerged due to the intensive agricultural activity in the basements was evaluated as Class 3 and identified with a light-green color. As move away from the plain, organic farming points increase and the colors on the map get darken. The map refers to areas where organic farming can be done in general (Anonymous, 2011).

It can be clearly seen on the map obtained as a result of the study, a large part of the basin is suitable for organic agricultural activities. The lack of limiting and polluting factors makes the basin suitable for organic agriculture.

\section{Discussion}

When academically meaningful organic agriculture is the issue, people first think of global warming, healthy living, and environmental pollution. Organic agriculture, identified with these issues, is shown by many authorities as a remedy to these problems. When current studies are examined, the emphasis is placed on the importance of organic farming for nutrition, the importance of the consumption of organic products in terms of maintaining human health, and minimizing health problems. The importance of organizing human food habits in the direction of organic agricultural products is emphasized and the issue of dissemination of organic products for the protection of future generations is at the forefront. Emphasizing the issue of organic agriculture in macro policymakers in the social sense also reveals the socio-economic dimension of organic agriculture. In particular, the increase in health expenditures, and the fact that they are pushing the countries economically with each passing day have shown that protection from the disease politically and economically is less costly than treatment.
Organic feeding of people is especially important in terms of preventing cancer and obesity problems, which are the most important health problems of the last years.

The point of emphasis in the national agriculture reports and action plans of the European Union, the OECD Trade and Agriculture Presidency, and the US Department of Agriculture, which are the world locomotives in agricultural production and rural development, is the sustainability issue. Ensuring sustainability in agriculture depends on the optimum use of resources. In particular, the negative environmental outcomes for the environment and the product are removed, and the use of renewable energy in production is emphasized. There is also the opinion that another important effect of organic agriculture is to reduce unemployment. Especially in conventional agricultural activities, the use of mechanized agricultural systems reduces the labor demand. Employment-based on agriculture is decreasing day by day. Organic agriculture is seen as an alternative to solve this problem. Organic agriculture is now being confronted as an important source for employment based on agriculture, as it is done in smaller areas and the labor intensity is 1.8 times higher than in conventional agriculture (Aktar and Ananias, 2005).

Our study aimed to reveal the organic farming potential of Kelkit basin. As can be seen clearly from the map, the basin is mostly suitable for organic agriculture. It is seen that the basin can adapt to the organic farming process very easily and provide a transition to it with a few precautions.

Propositions;

- Planning the appropriate product pattern,

- Training the producers about organic agriculture,

- Taking measures against polluting factors,

- Establishment of producer associations,

- Protection of water resources

- Establishment of product processing and packaging facilities

- Creation of the cold chain

- Joint development of livestock and crop production Kelkit Basin is very rich in terms of biodiversity. In the region, walnut cultivation is carried out as the main product in the field of fruit growing. Viticulture is common in Erbaa and Niksar regions. Local bean types are grown throughout the basin and some of them certified as organic. In the Upper Kelkit region, there are quite large and fertile pasture areas for organic livestock breeding. Beekeeping is carried out in many parts of the basin. Cultivating other products with organic certification, especially the main products grown in the basin, will ensure both the protection of the basin and the increase in economic income.

As a result, Kelkit basin; should be protected with a planned model in alternative income sources and declared total organic production basin for transferred to future generations.

\section{Authors' Contributions}

Hakan Karadağ: participated in data collection, analysis, description, and draft the manuscript. Kenan Yıldız: participated in supervision of the work starting from the proposal up to final draft: Hakan Mete Doğan: supervised, edited and revised the manuscript. 


\section{Conflict of Interest}

The authors declare that they have no conflict of interest.

\section{References}

Aktar, C., \& Ananias, V. (2005). Yeni bir ulusal politika: ekolojik tarım. Iktisat Islletme ve Finans, 20(229), 26-32.

Anonymous (2011). Diyarbakır İlinde Organik Tarıma Uygun Alanların Belirlenmesi ve Haritalanması Projesi, Sözleşme No: TRC2-10-DFD/30

Anonymous (2015a). Gida Tarım ve hayvancılık Bakanlığı Bitkisel Üretim Genel Müdürlügü, Türkiye Organik Tarım Stratejik Plan1 2012-2016

Anonymous (2015b).

TUIK. http://www.tuik.gov.tr/UstMenu.do?metod=temelist

Anonymous (2015c). Akşehir Organik Tarım Yaylacılık ve Kırsal Turizm Potansiyeli Fizibilitesi. Mevlana Kalkınma Ajansı.

Arslanoğlu, M., \& Özçelik, M. (2005). Sayısal Arazi Yükseklik Verilerinin İileştirilmesi. TMMOB Harita ve Kadastro Mühendisleri Odası 10. Türkiye Harita Bilimsel ve Teknik Kurultayı 28 Mart - 1 Nisan 2005, Ankara

Childs, C. (2004). Interpolating surfaces in ArcGIS spatial analyst. ArcUser, July-September, 3235(569), 32-35.

Davis, P.H. (1965-1988). Flora of Turkey and the East Aegean Islands. Vol. 1-10, Edinburgh University Press. Edinburgh.

Davis, P.H. (1971). Distribution patterns in Anatolia with particular reference to endemism. Plant Life of South-West Asia. Edited by Davis Harper and Hedge. Botanical Society of Edinburgh, Great Britain.

Deniz, E. (2009). Organik Tarım Sektör Raporu. Competitiveness and Innovation Framework Programme 2007-2013. Avrupa İşletmeler Ağı, Karadeniz, S:23

Demircan, M., Alan, İ., \& Şensoy, S. (2011). Coğrafi Bilgi Sistemleri Kullanarak Sicaklık Haritalarının Çözünürlüğünün Artırılması. TMMOB Harita ve Kadastro Mühendisleri Odası 13. Türkiye Harita Bilimsel ve Teknik Kurultayı 18-22 Nisan, Ankara

Demircan, M., Türkoğlu, N., \& Çiçek, İ. (2014). Mevsimlik Sicaklık Normallerinin (1971-2000) Coğrafî Bilgi Sistemleri İle Yüksek Çözünürlüklü Veri Setinin Üretilmesi. Coğrafya Sempozyumu, Ankara Üniversitesi Türkiye Coğrafyası Araştırma ve Uygulama Merkezi, 23-24.

Demiryürek, K. (2004). Dünya ve Türkiye'de organik tarım. Harran Üniversitesi Ziraat Fakültesi Dergisi, 8(3-4), 63 71.

Dogan, H. M. (2009). Mineral composite assessment of Kelkit River Basin in Turkey by means of remote sensing. Journal of Earth System Science, 118(6), 701-710.
Dogan, H. M., \& Kılıç, O. M. (2013a). Modelling and mapping some soil surface properties of Central Kelkit Basin in Turkey by using Landsat-7 ETM+ images. International journal of remote sensing, 34(15), 5623-5640.

Dogan, H. M., Yılmaz, D. S., \& Kılıç, O. M. (2013b). Orta Kelkit Havzası'nın bazıtoprak özelliklerinin ters mesafe ağırlık yöntemi (IDW) ile haritalanması ve yorumlanması. Gaziosmanpaşa Bilimsel Araştırma Dergisi, (6), 46-54.

Dolun, L. (2003). Organik Tarım. Türkiye Kalkınma Bankası A.Ş. Araştırma Müdürlüğü Matbaası, Ankara.

Dönmez, N., Yıldırım, M., \& Arslan, P. (2008). Obezite ve Kanser. Sağglık Bakanlığı Yayın No: 729, Ankara, s 20.

ESRI (1997). Understanding GIS the ARC/INFO Method. ISBN 1879102-01-3. California 92373-8100. USA.

ESRI (2016). Understanding Raster Interpolation. ArcGIS Resource Service. http://resources.esri.com/help/9.3/arcgisdesktop/com/gp_toolr ef/geoprocessing_with_3d_analyst/understanding_raster_inter polation.htm

FAO (2016). http://www.fao.org/faostat/en/\#data/RFN

FAO (2018a.) http://www.fao.org/faostat/en/\#data/RP

FAO (2018b). http://www.fao.org/faostat/en/\#data/RFN

Etko (2015). Catalogue of Measures. http://www.etko.org/Dosyalar/Belgeler/Belge_92.pdf

Karaer, F., (1994). Kelkit Vadisinin Floras1 ve Vejatasyonu, 19 Mayıs Üniversitesi, Fen Bilimleri Enstitüsü, Doktora Tezi.

Kennedy, P. (2000). 21. Yüzyıla Hazırlanırken. İş Bankası Kültür Yayınlar1, 3. Bask1, ISBN 9754580685, S:559

Korkmaz, K. (2007). Küresel Isınma ve Tarımsal Uygulamalara Etkisi, Alatarım, 6 (2), 43-49

Kılıç, O.M. (2015). Kelkit Havzası Ekolojik Risk Değerlendirmesi. Gaziosmanpaşa Üniversitesi, Fen Bilimleri Enstitüsü, Toprak Bilimi Bitki Besleme Anabilim Dalı, Doktora Tezi, Tokat

Lillesand, T.M., \& Kiefer, R.W. (2000). Remote Sensing and Image Interpretation 4 th ed.. ISBN 0-471-25515-7 John Wiley \& Sons. Inc..New York. USA.

Rehber, E., \& Turhan, S. (2002). Prospects and Challenges for Developing Countries in Trade and Production of Organic Food and Fibers: The Case of Turkey. British Food Journal 104(35), 371-390.

Shepard, D. (1968). A two-dimensional interpolation function for irregularly-spaced data. In Proceedings of the $196823^{\text {rd }}$ ACM national conference (pp. 517-524).

Üstünbaş, T. (2006). Sayisal Arazi Modellerinde Bazi Enterpolasyon Yöntemlerinin Karşilaştirilmasi. Selçuk-Teknik Dergisi, 5(2), 41-48.

Copyright: (C) 2021 by the authors. Turkish Journal of Food and Agriculture Sciences is licensed under a Creative Commons AttributionNonCommercial-NoDerivatives 4.0 International License 